\title{
KEMAMPUAN GURU BAHASA INDONESIA SMP NEGERI 1 SUMBAWA DALAM MENDESAIN DAN MENERAPKAN RENCANA PEMBELAJARAN TEKS HASIL OBSERVASI
}

\author{
Wiwik Surya Utami ${ }^{1}$, Rusdiawan ${ }^{2}$, Nuriadi $^{3}$ \\ Universitas Mataram \\ wiwiyunan@yahoo.com
}

\begin{abstract}
Abstrak
Penelitian ini bertujuan untuk mengetahui kemampuan guru bahasa Indonesia dalam mendesain dan menerapkan rencana pembelajaran teks hasil observasi di dalam kelas, yang mana di tinjau dari kesesuaian pokok materi pembelajaran yang telah dilaksanakan dengan RPP yang telah di desain pada awal semester. Penelitian ini menggunakan pedekatan kualitatif dengan metode deskriptif karena dalam penelitian ini bertujuan menggambarkan dan memaparkan isi dari objek yang akan diteliti.Sumber data penelitian adalah guru kelas VII SMP Negeri 1 Sumbawa yang merupakan salah satu sekolah favorit dan sekolah rujukan di kabupaten Sumbawa, itulah yang menjadi salah satu alasan memilih sekolah tersebut sebagai tempat penelitian.Teknik pengumpulan data yang digunakan adalah simak, baca, dengar, catat dan cakap. Teknik simak dipakai untuk mengumpulkan data dengan menyimak proses pembelajaran dikelas dengan menyesuaikan dengan RPP. Hasil dari penelitian ini menunjukkan bahwa kemampuan guru SMP Negeri 1 Sumbawa dalam menerapkan desain pembelajaran sudah dapat dikategorikan baik, sebagian besar dari butir-butir instrument penilaian pada kemampuan guru telah dapat di kuasai, namun perlu ada peningkatan komunikasi dan kerjasama dengan guru non PNS yang tidak tergabung dalam kelompok MGMP, sehingga guru non PNS tersebut dapat mengembangkan kemampuan mereka dalam mengajar dan menerapkan RPP didalam kelas. Guru yang pernah mengikuti pelatihan kurikulum 2013, serta tergabung dalam MGMP tentu akan sangat mempengaruhi kemampuan dalam membuat dan mendesain rancangan pembelajaran. Karena guru tersebut memiliki wawasan lebih dibandingkan guru yang jarang ikut serta pada pelatihan.
\end{abstract}

Kata kunci: Kemampuan guru, mendesain, menerapkan, teks observasi

\section{A. PENDAHULUAN}

Pendidikan merupakan investasi masa depan suatu bangsa. Kemajuan suatu negara sangat ditentukan oleh kualitas sumber daya manusia yang dapat dikembangkan melalui pendidikan. Pendidikan juga memberikan kontribusi yang sangat besar terhadap kemajuan suatu bangsa, dan wahana dalam mambangun watak bangsa serta menentukan model manusia yang di hasilkan. Bangsa akan tegak dan mampu menjaga martabat melalui pendidikan, karena pendidikan merupakan pilar tegaknya bangsa. Oleh karena itu, target utama pembangunan suatu negara termasuk Indonesia adalah pengembangan sumber daya manusia untuk menghasilkan manusia 
yang mampu berinovasi kreatif dan menjalin kerjasama dengan memanfaatkan teknologi yang dimilikinya sehingga dapat mengelola sumber daya alam yang tersedia.

Alat untuk mencapai tujuan pendidikan adalah kurikulum. Hal ini tertera pada UndangUndang Sistem Pendidikan Nasional Tahun 2003 Bab 1 Pasal 1 ayat 19 menyatakan bahwa: kurikulum adalah seperangkat rencana dan pengaturan mengenai tujuan, isi dan bahan pelajaran serta cara yang digunakan sebagai pedoman penyelenggara kegiatan belajar-mengajar (Depdiknas, 20013:3).

Komponen pendidikan yang sangat menentukan terselenggaranya proses pendidikan dengan baik adalah guru. Indra Djati Sidi (dalam Aryanti Dwiyani, 2012: 2) menyatakan guru adalah motor utama dalam pendidikan. Kreativitas dan inovasi guru harus selalu ditingkatkan demi menggapai kemajuan dan keberhasilan dalam membentuk sumber daya manusia Indonesia yang unggul dan berkualitas.Oleh karena itu, kehadiran guru yang professional sangat mempengariho terwujudnya program pendidikan nasional.

Namun, sampai saat ini guru belum melaksanakan tugasnya dengan baik sesuai dengan harapan karena berbagai faktor penghambat yang menghalanginya. Salah satu faktor penghambat tersebut adalah kemampuan guru itu sendiri belum menunjang pelaksanaan tugasnya. Salah satu tugas guru yang sangat penting dalam proses belajar mengajar yaitu kemampuan guru dalam mendesain rencana pembelajaran dikelas. Karena rencana pembelajaran sangatlah penting untuk mendukung terlaksananya proses belajar mengajar di dalam kelas.

Berdasarkan data SMP Negeri 1 Sumbawa merupakan salah satu sekolah rujukan di kabupaten Sumbawa dengan prestasi yang cukup membanggakan di berbagai mata pelajaran. Hal ini tidak lepas dari peran guru dalam mengajar di kelas, oleh karena itu, perlu sekiranya menjadi perhatian tentang kesiapan guru dalam mengajar dikelas dengan rancangan pembelajaran yang telah di buat oleh guru.Sehingga dapat menghasilkan siswa dengan prestasi yang sesuai dengan harapan. SMP Negeri 1 Sumbawa memiliki 8 guru pada bidang studi bahasa Indonesia, dari 7 guru tersebut terdapat 5 guru yang sudah pegawai negeri dan tersertertifikasi, tiga guru yang tersisa adalah tenaga honorer.

Berdasarkan uraian di atas, permasalahan yang muncul dalam proses pembelajaran adalah kemampuan guru mendesain rencana pembelajaran yang sesuai dengan pokok-pokok materi pembelajaran telah dilaksanakan dalam proses pembelajaran yang tertuang dalam RPP yang di buat oleh guru mata pelajaran bahasa Indonesia kelas VII pada bab teks hasil observasi. Konsep 
tersebut menarik peneliti untuk melihat secara dekat kemampuan guru bahasa Indonesia SMP Negeri 1 Sumbawa dalam mendesain dan menerapkan rencana pembelajaran teks hasil observasi.

\section{B. KAJIAN TEORI}

Penerapan kurikulum K13 dalam sistem pendidikan Indonesia tidak sekedar pergantian kurikulum, tetapi menyangkut perubahan fundamental dalam sistem pendidikan. Penerapan kurikulum 13 menuntut perubahan paradigm dalam pembelajaran dan persekolahan, karena dengan penerapan kurikulum K13 tidak hanya menyebabkan perubahan konsep, metode dan strategi guru dalam mengajar, tetapi juga menyangkut pola pikir, filosofis, komitmen guru, sekolah dan stakeholders pendidikan. Suatu keistimewaan dari kurikulum 2013 adalah menetapkan bahasa sebagai penghela ilmu pengetahuan (Nuh, 2013:37). Terdapat perubahan mendasar dalam kurikulum 2013, khususnya bidang pembelajaran bahasa Indonesia. Perubahan dimaksud terjadi pada paradigma penetapan satuan kebahasaan yang menjadi basis materi pembelajaran. Perubahan materi tersebut, membawa dampak pada perubahan metode pembelajaran, adapun satuan bahasa yang menjadi basis pembelajaran adalah teks (Mahsun, 2014:94).

Kurikulum sebagai program pendidikan, masih bersifat umum dan sangat ideal. Untuk merealisasikan dalam bentuk kegiatan yang lebih operasional yaitu dalam pembelajaran, tetapi terlebih dahulu guru harus memahami tuntutan kurikulum, kemudian secara praktis dijabarkan kedalam bentuk perencanaan pembelajaran untuk dijadikan pedoman operasional pembelajaran.Berdasarkan pernyataan dalam Undang -Undang Nomor 20 tahun 2003 tentang Sistem Pendidikan Nasional, bahwa salah satu tugas pokok guru atau pendidik adalah merencanakan proses pembelajaran, atau yang lebih dikenal dengan istilah Rencana Pelaksanaan Pembelajaran yang disingkat RPP. Dan Permendiknas No 41 Tahun 2007 tertanggal 23 Nopember 2007 tentang Standar Proses untuk Satuan Pendidikan Dasar dan Menengah, bahwa pengembangan Rencana Pelaksanaan Pembelajaran (RPP) dijabarkan dari silabus untuk mengarahkan kegiatan belajar peserta didik dalam upaya mencapai Kompetensi Dasar (KD)(BSNP, 2007).

Kehadiran guru dalam suatu proses pendidikan tetap memegang peranan penting dan tidak dapat digantikan oleh peralatan yang paling modern sekalipun. Keberhasilan pendidikan dan pembelajaran di sekolah tidak dapat dilepas dari peranan penting guru, sebab guru merupakan 
pelaksana paling depan dan pelaku utama, serta menjadi ujung tombak keberhasilan dan pelaksanaan pencapaian tujuan pendidikan dan pembelajaran. Itulah sebabnya setiap adanya inovasi pendidikan, khususnya dalam kurikulum dan peningkatan sumber daya manusia yang dihasilkan dari upaya pendidikan selalu bermuara pada faktor guru (Moh. Uzer Usman, 2006). Buku "Perencanaan Pembelajaran" yang diterbitkan oleh Departemen Pendidikan Nasional Direktorat Jenderal Pendidikan Dasar dan Menengah Direktorat Tenaga Kependidikan tahun 2004 disebutkan bahwa : Perencanaan pembelajaran (instruction design) adalah keseluruhan proses analisis kebutuhan dan tujuan belajar serta pengembangan sistem penyampaiannya untuk memenuhi kebutuhan dan mencapai tujuan belajar, termasuk didalamnya pengembangan paket pembelajaran dan kegiatan mengevaluasi program dan hasil belajar.

Oleh karena itu, ketika Pendidik dan tenaga kependidikan masih berpola fikir bahwa tugasnya adalah mengajar, bekerja hanya melaksanakan tugas dan rutinitas semata, maka akan sulit lingkungan pendidikan itu berubah menjadi lebih baik. Mereka justru tidak merasa berkewajiban untuk melakukan inovasi manajemen pendidikan supaya hasil pendidikannya jauh lebih baik.sebutan guru professional sejak zaman dahulu hingga kini, masih sering disebut-sebut atau digunakan. Guru professional yang harus memiliki empat kompetensi masing-masing kompetensi pedagogi, professional, kepribadian dan sosial itu masih menjadi harapan bagi pengembangan dunia pendidikan di tanah air.Harapan yang sudah sangat lama ditanam, bagai belum berbuah. Sejak para founding father negeri ini membangun grand design kemerdekaan Indonesia yang dituangkan dalam Pembukaan UUD 1945 hingga pada tujuan pembangunan nasional dan tujuan pendidikan nasional yang menempatkan guru pada kunci pembangunan bangsa.Guru harus menyadari peranan dan fungsi yang sangat penting dan strategis dalam proses pembelajaran di sekolah. Menurut Undang -Undang Nomor 20 tahun 2003 tentang Sistem Pendidikan Nasional dijelaskan bahwa pendidik merupakan tenaga profesional yang bertugas merencanakan dan melaksanakan proses pembelajaran,menilai hasil pembelajaran,melakukan pembimbingan dan pelatihan serta melakukan penelitian dan pengabdian pada masyarakat.

\section{METODE PENELITIAN}

Penelitian ini menggunakan pedekatan kualitatif dengan metode deskriptif karena dalam penelitian ini bertujuan menggambarkan dan memaparkan isi dari objek yang akan diteliti. Dan menurut Mahsun (2017:351) Data kualitatif dapat berupa hasil kerja/penugasan siswa, hasil 
kerja/penugasan guru, pandangan, pendapat, sikap responden, perilaku siswa atau guru, dokumen substansi materi/isi pembelajaran, dokumen kurikulum/silabus, dokumen RPP dan lain-lain.

Metode yang digunakan dalam penelitian ini adalah metode deskriptif. Penelitian ini mendeskripsikan bagaimana pokok-pokok materi pembelajaran telah dilaksanakan sesuai proses pembelajaran yang tertuang dalam RPP yang telah di buat oleh guru mata pelajaran Bahasa Indonesia pada bab teks hasil observasi yang menjadi sumber data.

Sumber data penelitian adalah guru kelas VII SMP Negeri 1 Sumbawa yang merupakan salah satu sekolah favorit dan sekolah rujukan di Kabupaten Sumbawa, itulah yang menjadi salah satu alasan memilih sekolah tersebut sebagai tempat penelitian.Teknik pengumpulan data yang digunakan adalah simak, baca, dengar, catat dan cakap.Teknik simak dipakai untuk mengumpulkan data dengan menyimak data yang ditetapkan pada RPP. Langkah-langkah untuk mengumpulkan data adalah: (1) menyimak/mengamati guru yang sedang mengimplementasikan rencana pembelajaran dalam proses pembelajaran di ruang kelas, (2). Mendengarkan penjelasan guru secara langsung pada saat proses pembelajaran, (3). Mencatat hal-hal yang relevan terutama bentuk perilaku guru secara utuh ketika menjelaskan materi pembelajaran, mulai dari pembuka sampai penutup pembelajaran, (4). Menanyakan pada guru dan siswa yang menjadi subyek dalam penelitian pembelajaran bahasa, (5). Menentukan kesesuaian pembelajaran di kelas dengan RPP yang telah di desain oleh guru.

\section{HASIL DAN PEMBAHASAN}

Penelitian ini memperoleh beberapa hasil penelitian berupa data penelitian. Data tersebut dideskripsikan sesuai dengan fakta dan kajian teori yang terkait.Pemaparan tersebut diuraikan dalam pembahasan.

1. Hasil penelitian

Hasil penelitian yang diperoleh adalah data dokumen, lembar penyimakan, dan wawancara. Data penelitian tersebut akan dirincikan sebagai berikut.

a. Data Dokumen

Dokumen yang dikumpulkan dalam penelitian ini adalah RPP teks hasil observasi (1 lembar) yang dibuat oleh guru pada awal semester, hasil lembar kerja siswa kelas VII tentang teks hasil observasi serta pedoman penilaian penugasan siswa yang tercantum didalam RPP. 
Berdasarkan ketiga dokumen tersebut tampak guru bahasa Indonesia kelas VII memiliki RPP yang sama walaupun berbeda guru. Guru PNS dan tersertifikasi dan guru non PNS. Tetapi di dalam penerapannya dikelas terdapat hal yang membedakan dari bagian menyampaikan tujuan pembelajaran, materi pembelajaran,penguasaan materi, kegiatan pembelajaran dan penilaian.

b. Data Simak

Metode simak merupakan metode yang digunakan dalam penyediaan data dengan cara peneliti melakukan penyimakan penggunaan atau perilaku dalam pembelajaran bahasa. Dalam menyadap perilaku guru pada proses pembelajaran berlangsung, peneliti tidak hanya sekedar menyadap dan menyaksikan, ia harus mencatat hal-hal yang relevan terutama bentuk perilaku guru secara utuh ketika menjelaskan materi pembelajaran, mulai dari pembuka sampai penutup pembelajaran (Mahsun, 2017:356). 


\section{Lembar Penyimakan}

\section{Kemampuan guru menerapkan rencana pembelajaran}

dalam proses pembelajaran di dalam kelas

\begin{tabular}{|c|c|c|c|c|}
\hline \multirow[t]{2}{*}{ No } & \multirow[t]{2}{*}{ Komponen yang Disimak } & \multirow[t]{2}{*}{ Aspek setiap Komponen } & \multicolumn{2}{|l|}{ Hasil } \\
\hline & & & $\begin{array}{c}\text { Guru } \\
\text { PNS }\end{array}$ & $\begin{array}{l}\text { Guru } \\
\text { Non } \\
\text { PNS }\end{array}$ \\
\hline A. & Tujuan Intruksional & & & \\
\hline 1 & $\begin{array}{l}\text { Rumusan kompetensi dasar dan } \\
\text { indikator yang menjadi tujuan } \\
\text { capaian belajar }\end{array}$ & $\begin{array}{l}\text { a. Tidak dijelaskan kepada siswa } \\
\text { sebelum pembelajaran dimulai. } \\
\text { b. Dinyatakan secara umum } \\
\text { sehingga siswa paham apa yang } \\
\text { akan dicapai dari pembelajaran } \\
\text { tersebut } \\
\text { c. Beberapa kompetensi dasar serta } \\
\text { indicator capaiannya dijelaskan } \\
\text { d. Semua kompetensi dasar serta } \\
\text { indicator capaiannya dijelaskan. }\end{array}$ & $\begin{array}{l}\mathrm{T} \\
\mathrm{Y} \\
\mathrm{Y} \\
\mathrm{Y}\end{array}$ & $\begin{array}{l}\mathrm{Y} \\
\mathrm{T} \\
\mathrm{T} \\
\mathrm{T}\end{array}$ \\
\hline 2 & $\begin{array}{l}\text { Ketepatan rumusan kompetensi } \\
\text { dasar beserta indicator capaian } \\
\text { pembelajaran dengan waktu } \\
\text { yang disediakan }\end{array}$ & \begin{tabular}{llr} 
a. & Indikator capaian pembelajaran \\
& terealisasi $25 \%$ & dalam \\
& pembelajaran & \\
b. & Indikator capaian pembelajaran \\
& terealisasi $50 \%$ dalam \\
& pembelajaran. \\
c. Indicator capaian pembelajaran & terealisasi $75 \%$ dalam \\
& \multicolumn{1}{l}{ pembelajaran. } \\
d. & Indikator capaian pembelajaran \\
& terealisasi semuanya dalam \\
& pembelajaran.
\end{tabular} & $\mathrm{T}$ & Y \\
\hline B & $\begin{array}{l}\text { Penguasaan } \\
\text { pembelajaran }\end{array}$ & & & \\
\hline
\end{tabular}




\begin{tabular}{|c|c|c|c|c|}
\hline 1 & $\begin{array}{lll}\begin{array}{l}\text { Substansi/ } \\
\text { pembelajaran }\end{array} & \text { isi } & \text { bahan } \\
\end{array}$ & $\begin{array}{l}\text { a. Bahan disalin/dibacakan oleh } \\
\text { guru atau siswa dari buku } \\
\text { sumber atau RPP. } \\
\text { b. Guru terlebih dahulu membaca } \\
\text { bahan atau menyuruh siswa } \\
\text { membacanya, kemudian guru } \\
\text { menjelaskan bahan tersebut } \\
\text { c. Guru menjelaskan secara lisan } \\
\text { isi bahan pembelajaran, sesekali } \\
\text { dia melihat buku sumber atau } \\
\text { RPP untuk menguji kebenaran } \\
\text { yang disampaikan } \\
\text { d. Guru menjelaskan secara lisan } \\
\text { juga mencatat dipapan tulis hal- } \\
\text { hal yang di anggap penting } \\
\text { disertai contohnya secara jelas } \\
\text { dengan tanpa melihat buku } \\
\text { sumber atau RPP }\end{array}$ & $\mathrm{Y}$ & Y \\
\hline 2 & $\begin{array}{l}\text { Keberurutan isi bahan } \\
\text { pembelajaran yang disampaikan } \\
\text { guru }\end{array}$ & 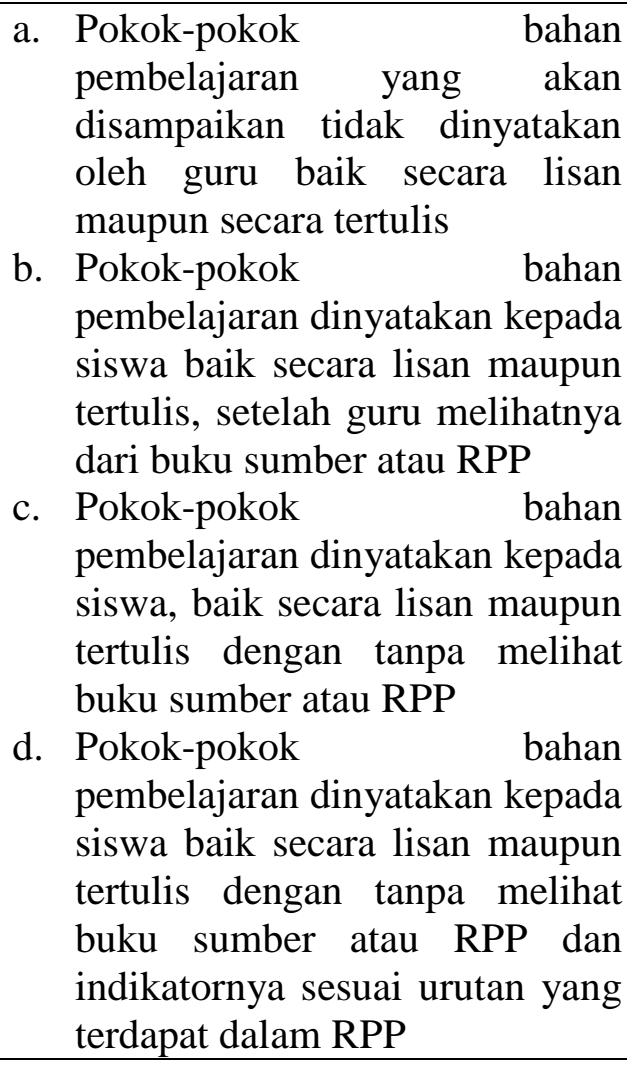 & Y & Y \\
\hline $\mathrm{C}$ & \multicolumn{4}{|l|}{ Kegiatan Pembelajaran } \\
\hline 1 & Metode Pembelajaran & a. Menggunakan & $\mathrm{T}$ & $\mathrm{Y}$ \\
\hline
\end{tabular}




\begin{tabular}{|c|c|c|c|c|c|}
\hline & & b. & 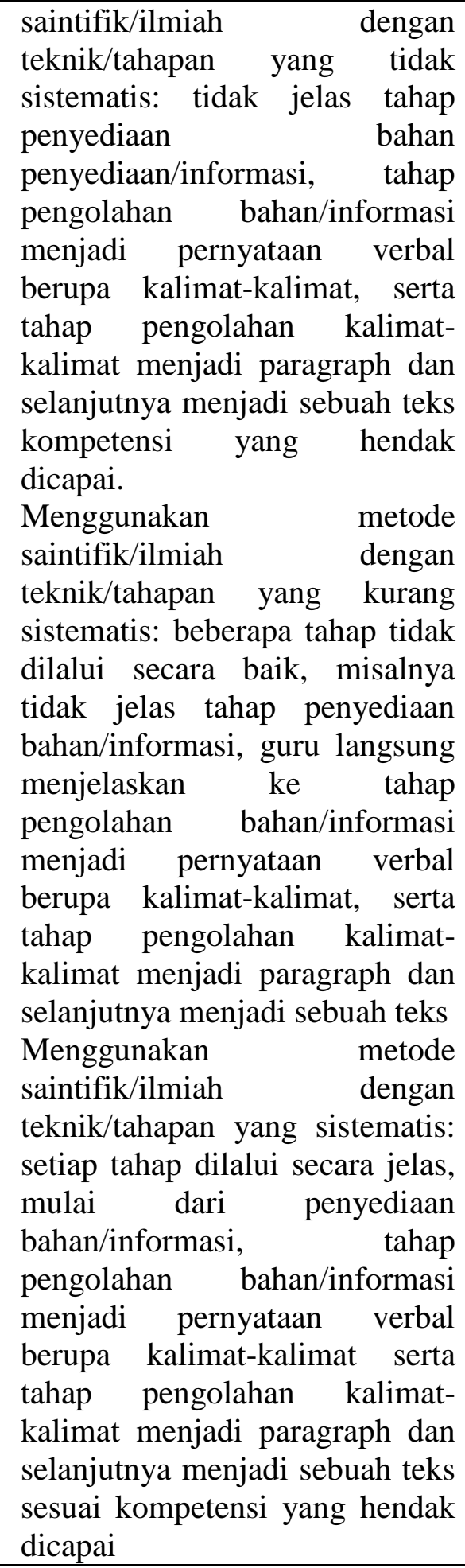 & $\mathrm{T}$ & Y \\
\hline 2 & Kegiatan siswa & a. & $\begin{array}{l}\text { Hanya } \\
\text { memerhatikan/mendengarkan } \\
\text { penjelasan yang disampaikan } \\
\text { guru } \\
\text { Di samping memerhatikan }\end{array}$ & $\mathrm{T}$ & Y \\
\hline
\end{tabular}




\begin{tabular}{|c|c|c|c|c|}
\hline & & $\begin{array}{l}\text { penjelasan guru, siswa juga } \\
\text { mengajukan pertanyaan hanya } \\
\text { ketika diminta oleh guru } \\
\text { c. Sebagian besar siswa } \\
\text { mengajukan pertanyaan } \\
\text { meskipun tanpa diminta oleh } \\
\text { guru } \\
\text { d. Siswa bertanya dan berdiskusi } \\
\text { serta melaksanakan tugas-tugas } \\
\text { dengan bantuan dan arahan guru }\end{array}$ & Y & $\mathrm{T}$ \\
\hline 3 & Media pembelajaran & $\begin{array}{llr}\text { a. } & \text { Tidak tersedia media } \\
\text { pembelajaran kecuali papan tulis } \\
\text { b. Menggunakan media } \\
\text { pembelajaran berupa gambar, } \\
\text { bagan yang disediakan terlebih } \\
\text { dahulu oleh guru atau oleh } \\
\text { sekolah } \\
\text { c. Selain menggunakan media } \\
\text { pembelajaran berupa gambar, } \\
\text { bagan digunakan juga media } \\
\text { berupa model, OHP dan lain- } \\
\text { lain }\end{array}$ & $\begin{array}{l}\mathrm{T} \\
\mathrm{Y}\end{array}$ & $\mathrm{T}$ \\
\hline 4 & $\begin{array}{l}\text { Kegiatan guru } \\
\text { pembelajaran }\end{array}$ & $\begin{array}{ll}\text { a. Lebih banyak memberikan } \\
\text { penjelasan secara lisan } \\
\text { b. Memberikan penjelasan disertai } \\
\text { media pembelajaran/alat peraga } \\
\text { c. Guru dan siswa sama-sama aktif } \\
\text { d. Siswa lebih banyak aktif } \\
\text { melakukan kegiatan } \\
\text { dibandingkan dengan keaktifan } \\
\text { guru dalam memberi penjelasan }\end{array}$ & $\begin{array}{l}\mathrm{T} \\
\mathrm{Y} \\
\mathrm{Y} \\
\mathrm{Y}\end{array}$ & $\begin{array}{l}\mathrm{Y} \\
\mathrm{Y} \\
\mathrm{Y} \\
\mathrm{Y}\end{array}$ \\
\hline 5 & Rangkuman Pembelajaran & $\begin{array}{l}\text { a. Tidak ada usaha baik dari guru } \\
\text { maupun siswa untuk } \\
\text { merangkum hasil pembelajaran } \\
\text { b. Guru menugasi siswa membuat } \\
\text { rangkuman hasil pembelajaran } \\
\text { c. Guru merangkum kembali } \\
\text { pokok-pokok penjelasan materi } \\
\text { pembelajaran dan siswa } \\
\text { mencatat dalam buku masing- } \\
\text { masing } \\
\text { d. Guru bersama siswa mencoba } \\
\text { secara bersama-sama membuat } \\
\text { rangkuman hasil pembelajaran }\end{array}$ & $\begin{array}{l}\mathrm{T} \\
\mathrm{T}\end{array}$ & $\begin{array}{l}\mathrm{T} \\
\mathrm{Y}\end{array}$ \\
\hline
\end{tabular}




\begin{tabular}{|c|c|c|c|c|}
\hline $\mathrm{D}$ & Penilaian & & & \\
\hline 1 & Pelaksanaan penilaian & $\begin{array}{l}\text { a. Guru tidak pernah bertanya } \\
\text { kepada siswa untuk mengukur } \\
\text { apakah materi riang } \\
\text { disampaikan telah dipahami } \\
\text { atau tidak oleh siswa, kecuali } \\
\text { bertanya untuk keperluan } \\
\text { menjelaskan atau membahas } \\
\text { atau dalam rangka apersepsi } \\
\text { b. Guru bertanya kepada beberapa } \\
\text { orang siswa secara lisan pada } \\
\text { akhir pembelajaran mengenai } \\
\text { bahan yang telah dijelaskan } \\
\text { c. Guru melaksanakan tes awal, tes } \\
\text { tambahan, tes akhir secara lisan } \\
\text { kepada beberapa orang siswa } \\
\text { d. Guru memberikan tes awal dan } \\
\text { tes tambahan secara lisan } \\
\text { sedangkan tes akhir diberikan } \\
\text { secara tertulis kepada semua } \\
\text { siswa yang menggambarkan } \\
\text { indicator capaian pembelajaran }\end{array}$ & Y & $\mathrm{T}$ \\
\hline 2 & Isi/Substansi pertanyaan & $\begin{array}{l}\text { a. Isi pertanyaan hanya } 25 \% \text { yang } \\
\text { sesuai dengan indicator capaian } \\
\text { pembelajaran } \\
\text { b. Isi pertanyaan mencapai } 50 \% \\
\text { dari keseluruhan indicator } \\
\text { capaian pembelajaran } \\
\text { c. Isi pertanyaan mencapai } 75 \% \\
\text { dari keseluruhan indicator } \\
\text { capaian pembelajaran } \\
\text { d. Semua isi pertanyaan } \\
\text { menggambarkan semua } \\
\text { indicator capaian pembelajaran }\end{array}$ & $\mathrm{T}$ & $\mathrm{T}$ \\
\hline 3 & $\begin{array}{l}\text { Hasil yang dicapai siswa jika } \\
\text { ada pertanyaan pada akhir } \\
\text { pembelajaran }\end{array}$ & $\begin{array}{l}\text { a. Hanya } 25 \% \text { jawaban siswa } \\
\text { yang dijawab dengan benar } \\
\text { b. Jawaban siswa yang benar } \\
\text { mencapai } 50 \% \\
\text { c. Jawaban siswa yang benar } \\
\text { mencapai } 78 \% \\
\text { d. Semua pertanyaan dijawab } \\
\text { oleh siswa dengan benar }\end{array}$ & $\begin{array}{l}\mathrm{T} \\
\mathrm{T} \\
\mathrm{T} \\
\mathrm{Y}\end{array}$ & $\mathrm{T}$ \\
\hline 4 & Tindak Lanjut & $\begin{array}{l}\text { a. Setelah mendapat jawaban } \\
\text { yang salah dari siswa atas } \\
\text { pertanyaannya, guru tidak }\end{array}$ & $\mathrm{T}$ & $\mathrm{T}$ \\
\hline
\end{tabular}




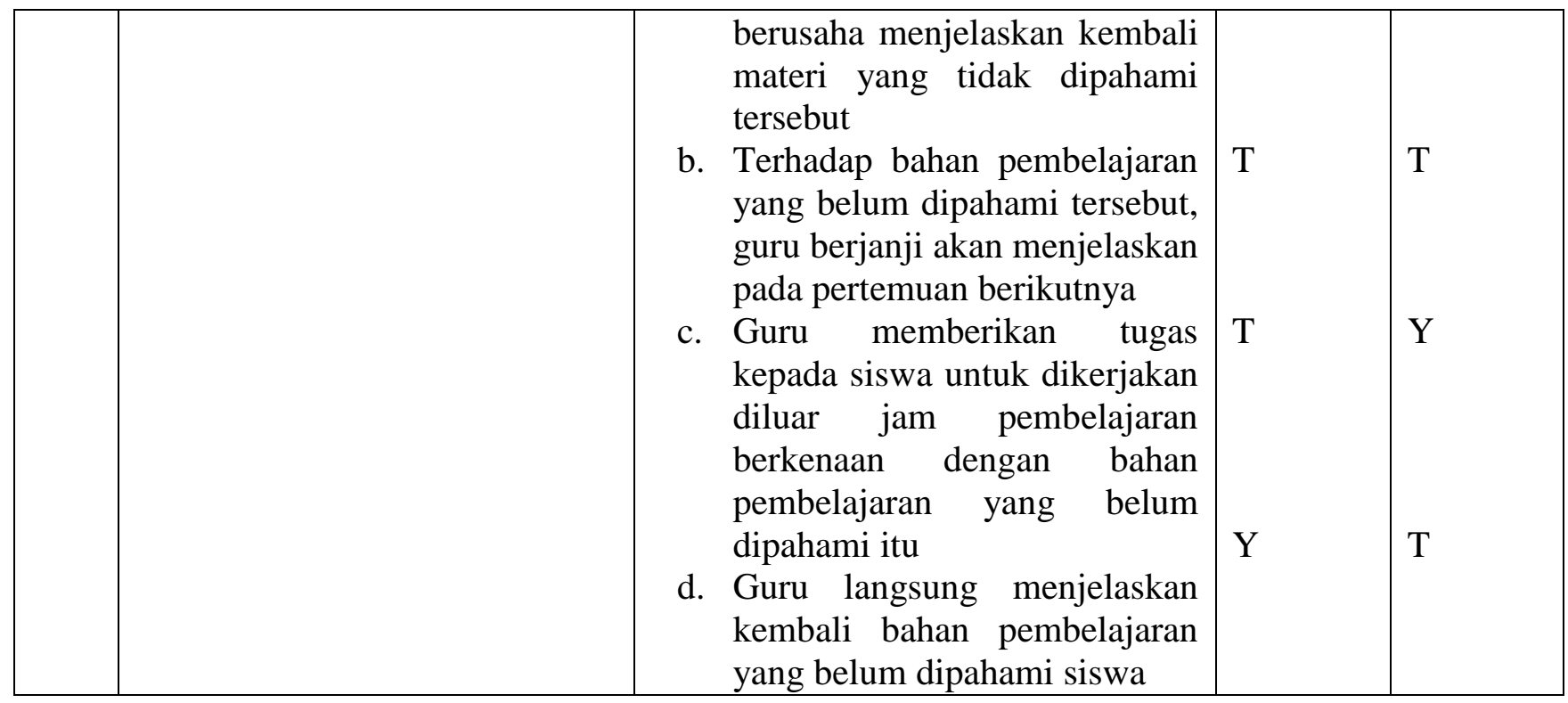

Dari hasil pengamatan peneliti di dalam kelas pada saat proses belajar mengajar kelas VII untuk bab teks hasil observasi, peneliti dapat mengambil kesimpulan dari 3 guru yang mengajarkan pelajaran bahasa Indonesia di kelas VII terdapat satu guru PNS dan bersertifikasi yang mengajar 4 kelas dan 4 kelas berikutnya di ajar oleh 2 guru honorer. Yang mana guru PNS tersebut sudah pernah mengikuti pelatihan kurikulum 2013 dan tergabung dalam forum musyawarah guru mata pelajaran (MGMP), berbeda dengan guru honorer yang tidak ikut serta dalam pelatihan maupun MGMP.

Dari data di atas dapat kita lihat bahwa guru PNS dapat mengajar dengan baik dan sesuai dengan RPP yang telah di desain pada awal semester.Sedangkan guru honorer masih memiliki beberapa kekurangan dalam menerapkan rancangan pembelajaran di dalam kelas.

Dari sudut pandang siswa cara pengajaran guru PNS lebih menarik dan mudah dipahami dibandingkan dengan guru honorer. Walaupun begitu ada beberapa siswa juga merasa pengajaran dari guru honorer mudah dipahami dan diikuti.

\section{c. Data Wawancara}

Data wawancara adalah data yang diperoleh dari guru mata pelajaran bahasa Indonesia. Wawancara yang dilakukan untuk memperoleh deskripsi mengenai kesesuaian pokok materi pembelajaran yang telah dilaksanakan sesuai dengan proses pembelajaran yang tertuang dalam RPP. Berdasarkan hasil wawancara dengan guru mata pelajaran dapat diketahui bahwa dalam 
mendesain rancangan rencana pembelajaran (RPP) ini guru menyusun dalam kelompok mata pelajaran yang dipimpin oleh ketua MGMP.Dan guru yang tergabung dalam MGMP di sekolah SMP Negeri 1 Sumbawa hanya guru-guru PNS.Karena kemampuan membuat RPP merupakan langkah awal yang harus dimiliki guru,dan sebagai muara dari segala pengetahuan teori,keterampilan dasar, dan pemahaman yangmendalam tentang objek belajar dan situasipembelajaran.Adapunkomponen-komponen RPP yang terdiri dari 1).Identitas mata pelajaran, 2) Standar kompetensi, 3)Kompetensi dasar, 4) Indikator pencapaian kompetensi.5) Tujua pembelajaran, 6) Materi ajar,7) Alokasi waktu, 8) Metode pembelajaran, 9)Kegiatan pembelajaran, 10) Penilaian hasil belajardan 10).Sumber belajar.

\section{Pembahasan}

Kesesuaian antara pokok-pokok materi pembelajaran yang telah dilaksanakan dengan RPP menjadi sangat penting untuk diperhatikan karena RPP dikembangkan dari silabus untuk mengarahkan kegiatan pembelajaran peserta didik dalam upaya mencapai kompetensi dasar (Salinan Permendikbud No. 65 Tahun 2013).RPP dikembangkan untuk satu kegiatan tatap muka atau lebih. Sebagai contoh, untuk pelajaran bahasa Indonesia, satu RPP dikembangkan untuk 2-6 tatap muka, tergantung dari tingkat keluasan dan kedalaman KD yang dibelajarkan. Tujuan dari pengembangan RPP supayan aktivitas belajar-mengajar yang dilaksanakan benar-benar dapat mencapai kompetensi dasar yang telah di canangkan (Endah Tri Priyatni, 2017:161)

Kemampuan guru SMP Negeri 1 Sumbawa dalam menerapkan desain pembelajaran sudah dapat dikategorikan baik, sebagian besar dari butir-butir instrument penilaian pada kemampuan guru telah dapat di kuasai, namun perlu ada peningkatan komunikasi dan kerjasama dengan guru non PNS yang tidak tergabung dalam kelompok MGMP, sehingga guru non PNS tersebut dapat mengembangkan kemampuan mereka dalam mengajar dan menerapkan RPP didalam kelas.

Guru yang pernah mengikuti pelatihan kurikulum 2013, serta tergabung dalam MGMP tentu akan sangat mempengaruhi kemampuan dalam membuat dan mendesain rancangan pembelajaran. Karena guru tersebut memiliki wawasan lebih dibandingkan guru yang jarang ikut serta pada pelatihan.Mardapi (2012: 2-3), keberhasilan guru dalam melaksanakan proses pembelajaran ditentukan oleh kompetensi yang di miliki guru. Guru yang memiliki kompetensi sebagai pendidik akan lebih berhasil dalam melaksanakan pembelajaran dibandingkan dengan 
guru yang tidak memiliki kompetensi. Keberhasilan dalam melaksanakan pembelajaran akan meningkatkan prestasi belajar peserta didik yang selanjutnya akan meningkatkan kualitas pendidikan.

\section{E. SIMPULAN}

Kemampuan guru dalam mendesain rancangan pembelajaran yang sesuai dengan materi di dalam kelas merupakan hal yang sangat penting untuk mencapai tujuan pendidikan yang ingin di capai. Karena pada dasarnya para pendidik di setiap satuan pendidikan berkewajiban menyusun RPP secara lengkap dan sistematis agar pembelajaran dapat berlangsung secara interaktif, inspiratif, menyenangkan, menantang, efisien, memotivasi peserta didik untuk berpartisipasi aktif, serta memberikan ruang yang cukup bagi prakarsa, kreativitas dan kemandirian sesuai dengan bakat, minat, dan perkembangan fisik, serta psikologis peserta didik (Salinan Permendikbud No. 65 Tahun 2013)

Oleh karena itu, sangatlah penting penguasaan guru dalam menerapkan RPP dikelas. Karena dengan penguasaan RPP maka pembelajaran dikelas akan dapat berlangsung efektif.

\section{DAFTAR PUSTAKA}

Depdiknas. 2003. Undang-Undang Republik Indonesia Nomor 20 Tahun 2003 Tentang sistem Pendidikan Nasional. Jakarta: Depdiknas.

Dwiyani, Aryanti. Kefektifan Kinerja Guru Sains Dalam Mengiplementasikan KTSP di SMP/MTs Negeri Se-kecamata Sumbawa Kabupaten Sumbawa. Yogyakarta: Universitas Negeri Yogyakarta

Nuh, Muhammad. 2013. Menyemai Kreator Peradaban: Renungan tentang Pendidikan Agama dan Budaya. Jakarta: Zaman

Mahsun.2014. Teks Dalam Pembelajaran Bahasa Indonesia Kurikulum 2013. Jakarta. Rajawali Pers.

Mahsun. 2017. Metode Penelitian Bahasa. Jakarta. Rajawali Pers

Moleong. 2000. Metodologi Penelitian Kualitatif. Badung. PT. Remaja Rosda Karya

Muh. Uzer Usman. 2006. Menjadi guru professional. Bandung. PT Remaja Rosda Karya

Priyatni, Tri. Endah.2017. Desain Pembelajaran Bahasa Indonesia Dalam Kurikulum 2013. Jakarta. PT. Bumi Aksara. 